\title{
Pengaruh Profitabilitas, Kepemilikan Institusional, Kebijakan Dividen dan Leverage Terhadap Nilai Perusahaan
}

\author{
Nuri Ari Hidayati ${ }^{1}$ Umaimah $^{2 *}$ \\ Universitas Muhammadiyah Gresik, Jl. Sumatra 101, Gresik, Indonesia
}

\section{Http://}

\section{Abstract}

This study aims to determine how much influence profitability, institutional ownership, dividend policy, and leverage on firm value at LQ 45 companies in 2016-2019. This research uses quantitative methods and uses secondary data as a data source. The sampling technique used was the purposive sampling technique and obtained data of 108 company samples. The data analysis technique used is multiple linear regression analysis. The results showed that profitability, which is proxied by return on equity (ROE), affects firm value. Institutional ownership variable which is proxied by institutional (INST) and dividend policy which is proxied by dividend payout ratio (DPR) does not affect firm value. The leverage variable which is proxied by the debt to asset ratio (DAR) affects firm value in a negative direction.

Type article: Empirical

Keywords : Profitability, Institutional Ownership, Dividend Policy, Leverage, Firm Value

\section{Pendahuluan}

Nilai Perusahaan merupakan salah satu hal yang menjadi tolak ukur investor yang kaitannya dengan harga saham sebuah perusahaan. (Wijaya \& Sedana, 2015) mengatakan bahwa tingginya harga saham maka berbanding lurus dengan nilai perusahaan. Sedangkan ketidakpastian kondisi ekonomi saat ini membuat harga saham berubah-ubah secara tak terduga. Dengan adanya kondisi yang seperti ini, bisa mengakibatkan nilai perusahaan menjadi menurun.

Investor lebih memilih menanamkan modal sahamnya pada perusahaan yang mempunyai kinerja yang baik dalam mengoptimalkan nilai perusahaan. Perusahaan dengan nilai perusahaan baik bisa dilihat dari harga sahamnya yang stabil dan mengalami eskalasi dari waktu ke waktu dalam jangka panjang. Adanya peningkatan harga saham membuat

\footnotetext{
${ }^{*}$ Kontal penulis:

Email: umaimah@umg.ac.id

Institusi: Universitas Muhammadiyah Gresik
} 
kemakmuran para agen juga meningkat. Alasan dilakukannya penelitian ini dikarenakan dalam berinvestasi, nilai perusahaan merupakan salah satu tolak ukur yang wajib untuk dipertimbangkan. Hal ini dikarenakan nilai perusahaan mencerminkan bagaimana kinerja manajemen dari perusahaan tersebut.

Nilai perusahaan dapat diukur dengan harga saham dengan menggunakan rasio yang dinamakan rasio penilaian. Rasio penilaian bisa memberikan informasi seberapa besar masyarakat menghargai perusahaan, sehingga dengan nilai yang baik dapat membuat masyarakat tertarik untuk menginvestasikan modalnya untuk membeli saham dengan harga lebih tinggi dibandingkan dengan nilai bukunya. Kejelian dalam menilai tersebut dibutuhkan oleh investor dalam menginvestasikan modalnya. Apabila salah memilih bisa merugikan investor tersebut.

Penelitian tentang nilai perusahaan dengan menggunakan teori sinyal banyak dilakukan, yakni oleh (Dwi \& Pradnyana, 2018) (Martha et al., 2018). Dari hasil analisis data yang dilakukan peneliti terdahulu menunjukkan hasil yang bermacam ragam. Penelitian yang dilakukan oleh (Dwi \& Pradnyana, 2018) didapatkan hasil nilai perusahaan secara positif dipengaruhi oleh profitabilitas. Profitabilitas memiliki kemampuan untuk mempengaruhi nilai perusahaan, faktor ini disebabkan dengan nilai profitabilitas yang semakin meningkat bisa berimbas terhadap penambahan nilai perusahaan manufaktur yang terdaftar di Bursa Efek Indonesia (BEI). Penelitian (Martha et al., 2018) memperoleh hasil bahwa nilai perusahaan secara positif dan signifikan dipengaruhi oleh profitabilitas. Penelitian lain juga dilakukan oleh (Apriada \& Suardhika, 2016), dimana penelitian tersebut menunjukkan bahwa profitabilitas secara negatif berpengaruh terhadap nilai perusahaan. Penelitian yang dilakukan oleh (Mardevi et al., 2020) didapatkan hasil bahwa nilai perusahaan dapat dipengaruhi oleh likuiditas dan profitabilitas. Berdasarkan penelitian yang dilakukan (Oktrima, 2017) didapatkan hasil, profitabilitas yang dihitung dengan Return on Assets (ROA) tidak berpengaruh terhadap nilai perusahaan yang dihitung dengan Prive Book Value (PBV).

Kepemilikan institusional juga mempengaruhi nilai perusahaan. Kepemilikan institusional dapat digunakan untuk meminimalisir akibat dari adanya konflik agency theory dalam kepemilikan manajerial. Hal ini sejalan dengan yang dikatakan oleh (Sinarmayarani \& Suwitho, 2016) diyakini bahwa kepemilikan institusional memiliki kontribusi guna meminimalkan adanya konflik keagenan yang terjadi di antara manajer dan pemegang saham, keberadaan investor institusional mampu untuk memekanisme monitoring yang efektif dalam setiap keputusan yang diambil oleh manajer.

Penelitian dengan menggunakan teori sinyal dilakukan oleh (Apriada \& Suardhika, 2016) dari hasil uji datanya menunjukkan hasil bahwa nilai perusahaan dipengaruhi oleh kepemilikan institusional. (Widianingsih, 2018) telah melakukan penelitian dimana berdasarkan hasil penelitiannya didapatkan hasil bahwa kepemilikan institusional berpengaruh terhadap nilai perusahaan. Sedangkan penelitian yang dilakukan oleh (Dewi \& Abundanti, 2019) didapatkan hasil yang tidak searah dengan hasil penelitian yang dilakukan peneliti lainnya, berdasarkan penelitian tersebut didapatkan output bahwa kepemilikan institusional berpengaruh negatif dan signifikan terhadap nilai perusahaan. (Lestari, 2017) berdasarkan hasil penelitian didapatkan output bahwa nilai perusahaan secara positif dan signifikan dipengaruhi oleh kepemilikan institusional. Penelitian yang dilakukan (Sinarmayarani \& Suwitho, 2016) didapatkan hasil, secara signifikan nilai perusahaan berpengaruh terhadap nilai perusahaan.

Terdapat Faktor lain yang dapat mempengaruhi nilai perusahaan yaitu kebijakan dividen. Dimana kebijakan dividen ini merupakan sebuah kebijakan yang disetujui bersama oleh pihak perusahaan dalam hal penetapan proporsi laba yang diterima oleh perusahaan untuk dibayar kepada pihak pemegang saham sesuai dengan total saham yang dimiliki pihak shareholder (Senata, 2016). (Ulistianingsih \& Yuniati, 2016) dalam penelitiannya digunakan kebijakan dividen, kepemilikan manajerial dan profitabilitas dengan menggunakan teori keagenan , dimana di dalam penelitiannya diperoleh hasil bahwa kebijakan dividen yang dihitung dengan menggunakan DPR ( Dividend Payout Ratio) memiliki pengaruh yang positif terhadap nilai perusahaan. (Idawati, 2016) juga melakukan penelitian dimana hasil uji penelitian tersebut menunjukan kebijakan dividen berpengaruh secara signifikan terhadap nilai perusahaan. Kebijakan dividen yang diukur dengan Dividend Payout Ratio (DPR) berpengaruh signifikan terhadap nilai perusahaan (Wardhani et al., 2017).

Leverage juga merupakan salah satu faktor yang mempengaruhi nilai perusahaan. Leverage merupakan kemampuan perusahaan dalam membayar hutang dengan menggunakan 
modal yang dimiliki perusahaan tersebut. Menurut (Arifianto \& Chabachid, 2016) berdasarkan hasil penelitiannya menunjukkan bahwa leverage secara negatif dan signifikan berpengaruh terhadap nilai perusahaan. Ketika perusahaan mempunyai nilai rasio leverage yang tinggi maka dapat dikatakan bahwa perusahaan tersebut mempunyai rasio hutang yang lebih tinggi dibandingkan dengan jumlah aset yang dipunyai oleh perusahaan tersebut..

Menurut penelitian yang dilakukan (Rahayu \& Sari, 2018) dengan menggunakan teori agensi menunjukkan bahwa leverage dapat mempengaruhi nilai perusahaan. (Tewuh et al., 2020) dalam penelitiannya menunjukkan hasil bahwa leverage secara signifikan tidak berpengaruh terhadap nilai perusahaan. Dalam menambah hutang, perusahaan disarankan agar selalu hati-hati agar terjadi keseimbangan antara pengorbanan dengan manfaat. Sehingga, perusahaan dapat membagi dividen dan ekspektasi dari pemegang saham bisa terpenuhi. Berdasarkan penelitian yang dilakukan oleh (Dewi lusiana \& Agustina, 2017) didapatkan hasil bahwa nilai perusahaan dipengaruhi oleh kepemilikan manajerial. Nilai perusahaan tidak dipengaruhi oleh leverage. (Suwardika \& Mustanda, 2017) dalam penelitiannya memperoleh hasil bahwa secara signifikan dan positif nilai perusahaan dipengaruhi oleh leverage.

Berdasarkan berbagai macam penelitian yang telah dilakukan oleh peneliti terdahulu masih banyak penelitian yang menunjukkan hasil yang tidak konsisten. Berdasarkan uraian latar belakang di atas, peneliti tertarik untuk melakukan penelitian dengan judul "Pengaruh Profitabilitas, Kepemilikan Institusional, Kebijakan Dividen dan Leverage Terhadap Nilai Perusahaan".

\section{Tinjauan Pustaka}

\subsection{Teori Sinyal}

Menurut (Gumanti, 2009:4) signalling theory merupakan sebuah usaha yang dilakukan oleh pihak manajemen untuk memberikan isyarat (sinyal) terhadap pihak pemegang saham (investor) tentang bagaimana kondisi perusahaan pada saat itu baik dalam segi nilai profitabilitas, umur perusahaan maupun nilai perusahaan. Sinyal tersebut bisa dalam berbagai bentuk, baik secara langsung dapat diamati maupun memerlukan telaah untuk bisa memahaminya. Berbagai bentuk sinyal yang diberikan terhadap pihak luar tujuannya tetap sama, yaitu untuk memberikan sinyal maupun isyarat agar pihak investor mampu memberikan perubahan penilaian terhadap perusahaan, sehingga nilai perusahaan bisa meningkat.

\subsection{Teori Keagenan}

Agency theory atau teori keagenan merupakan hubungan keagenan sebagai sebuah kontrak di mana satu maupun lebih (prinsipal) yang melibatkan orang lain (agen) untuk melakukan beberapa layanan dengan nama mereka yang dimana di dalamnya melibatkan pendelegasian tugas dalam pengambilan suatu keputusan (Jensen \& Meckling, 1976). (Raharjo, 2007:37) menyebutkan bahwa teori agensi terpusat dengan individu yaitu agen dan principal. Dari segi prinsipal maupun agen, mereka diasumsikan sebagai orang ekonomi yang rasional yang memiliki motivasi untuk memenuhi kepentingan sendiri, namun mereka kesulitan membedakan penghargaan atas preferensi, kepercayaan maupun informasi.

\subsection{Nilai Perusahaan}

Menurut (Sartono, 2010:487) Nilai perusahaan merupakan nilai jual suatu perusahaan sebagai sebuah bisnis yang sedang beroperasi. Nilai perusahaan adalah sebuah nilai yang bisa digunakan untuk mengukur seberapa besar tingkat kepentingan suatu perusahaan bisa dilihat dari sudut pandang beberapa pihak seperti investor yang mengaitkan nilai suatu perusahaan dari harga sahamnya. Tujuan jangka panjang dari sebuah perusahaan adalah memajukan nilai perusahaan. Nilai perusahaan yang tinggi menggambarkan kesejahteraan pemiliknya juga tinggi. (Riyanto, 2010:22) mengatakan, peningkatan harga saham sebuah perusahaan merupakan suatu prestasi yang sesuai dengan meningkatnya nilai suatu perusahaan. 


\subsection{Profitabilitas}

Profitabilitas adalah gambaran kinerja manajemen dalam mengelola sebuah perusahaan (Petronila \& Mukhlasin, 2003). (Sartono, 2010:122) Profitabilitas adalah gambaran suatu perusahaan, bagaimana perusahaan tersebut menghasilkan laba dari modal ataupun kekayaan yang dimiliki perusahaan tersebut. Ketika keuntungan perusahaan meningkat, maka nilai perusahaan juga mengikutinya. Nilai profitabilitas yang tinggi diyakini mampu untuk menarik minat investor untuk menanamkan modalnya. Ketika minat investor mengalami kenaikan maka akibatnya dapat menyebabkan harga saham perusahaan juga akan meningkat.

\subsection{Kepemilikan Institusional}

Kepemilikan institusional adalah kepemilikan saham yang dimiliki oleh perusahaan oleh lembaga keuangan non bank maupun institusi, yang mengelola dana orang lain (Pasaribu et al., 2016). Tingkat kepemilikan saham institusional menyebabkan tingkat pengendalian yang dilakukan pihak eksternal terhadap perusahaan semakin tinggi pula. Akibatnya agency cost di dalam perusahaan berkurang dan nilai perusahaan semakin meningkat. (Sholekah \& Venusita, 2014) dalam penelitiannya menyebutkan kepemilikan institusional diproksikan dengan INST, yang berarti perbandingan antara jumlah saham yang dimiliki institusional terhadap jumlah saham yang beredar.

\subsection{Kebijakan Dividen}

Kebijakan dividen atau dividend policy merupakan keputusan yang disetujui oleh perusahaan tentang apakah keuntungan yang didapatkan oleh suatu perusahaan dalam satu periode akan dibagikan kepada pemegang saham dalam bentuk dividen atau ditahan untuk meningkatkan modal yang dialokasikan untuk membiayai investasi di masa yang akan datang (Sutrisno, 2009:266). Dividend payout ratio atau rasio pembayaran dividen juga menentukan jumlah saldo laba bagi perusahaan untuk sumber pendanaan.

\subsection{Leverage}

Leverage adalah rasio yang diimplementasikan untuk mengetahui seberapa besar kapasitas perusahaan untuk membayar seluruh kewajibannya ( baik long term maupun short term ) (Kasmir, 2012:151). Leverage ratio dapat digunakan untuk mengukur seberapa besar dana yang didistribusikan oleh pemilik perusahaan dalam proporsinya dengan dana yang didapat dari kreditur. Rasio leverage yang meningkat dapat menurunkan nilai perusahaan. Hal ini dikarenakan ketika perusahaan yang memiliki rasio leverage tinggi menunjukkan bahwa perusahaan tersebut memiliki rasio hutang yang lebih tinggi dibandingkan dengan aset yang dimiliki perusahaan tersebut.

\subsection{Pengembangan Hipotesis}

\subsubsection{Pengaruh Profitabilitas Terhadap Nilai Perusahaan}

Profitabilitas merupakan indikator yang dilakukan manajemen dalam mengelola kekayaan yang dimiliki perusahaan yang dicerminkan dengan laba yang dihasilkan. (Petronila \& Mukhlasin, 2003) dan (Suharli et al., 2006) mendefinisikan bahwa profitabilitas merupakan gambaran dari kinerja manajemen dalam mengelola suatu perusahaan. Perusahaan yang bisa menjaga kestabilan serta meningkatkan laba bisa dilihat sebagai sinyal positif oleh investor yang berkaitan dengan kinerja perusahaan (Rizqia et al., 2013).

Penelitian yang dilakukan oleh (Lubis et al., 2017) dengan menggunakan teori keagenan menunjukkan profitabilitas berpengaruh positif dan signifikan terhadap nilai perusahaan. (Ayu 
\& Suarjaya, 2017) dengan menggunakan teori sinyal menunjukkan profitabilitas berpengaruh positif dan signifikan terhadap nilai perusahaan.

$\mathrm{H}_{1}$ : Profitabilitas Berpengaruh Terhadap Nilai Perusahaan

\subsubsection{Pengaruh Kepemilikan Institusional Terhadap Nilai Perusahaan}

Dalam penelitian yang dilakukan oleh (Haruman, 2008) menyebutkan bahwa kepemilikan institusional memiliki peran dalam memperbaiki pengelolaan perusahaan yang bisa mempengaruhi kinerja dan bisa meningkatkan nilai perusahaan. Adanya pengawasan yang semakin ketat, sebaiknya manajer semakin bertanggung jawab dalam mengelola dan mengembangkan perusahaan, dengan harapan kinerja perusahaan dapat semakin baik sehingga nilai pengembalian yang diperoleh pemegang saham institusional bisa semakin tinggi.

Nilai perusahaan dapat dipengaruhi oleh kepemilikan institusional, dimana hal ini dibuktikan dengan hasil penelitian yang telah dilakukan oleh (Jayaningrat et al., 2017) dengan mengaplikasikan teori sinyal yang menunjukkan bahwa kepemilikan institusional memiliki pengaruh positif dan signifikan terhadap nilai perusahaan. (Hamdiah, 2015) dengan mengaplikasikan teori keagenan dalam penelitiannya juga menyebutkan bahwa kepemilikan institusional memiliki pengaruh terhadap nilai perusahaan.

$\mathrm{H}_{2}$ : Kepemilikan Institusional Berpengaruh Terhadap Nilai Perusahaan

\subsubsection{Pengaruh Kebijakan Dividen Terhadap Nilai Perusahaan}

Kebijakan dividen berdasarkan teori sinyal hingga saat ini masih menimbulkan perdebatan. Teori sinyal menyatakan jika semakin maksimal dividen yang dibagikan terhadap pemegang saham, makan kinerja perusahaan akan dianggap semakin baik. Akibatnya harga saham perusahaan akan semakin meningkat. Penelitian yang dilakukan oleh (Putra \& Lestari, 2016) dan (Rai Prastuti \& Merta Sudiartha, 2016) menunjukkan bahwa kebijakan dividen berpengaruh positif dan signifikan terhadap nilai perusahaan.

\section{$\mathrm{H}_{3}$ : Kebijakan Dividen Berpengaruh Terhadap Nilai Perusahaan}

\subsubsection{Pengaruh Leverage Terhadap Nilai Perusahaan}

Leverage adalah implementasi hutang oleh perusahaan untuk melakukan kegiatan operasional perusahaan. Perusahaan yang memiliki rasio leverage kecil menjadi salah satu faktor yang bisa menarik minat investor untuk menanamkan dananya ke perusahaan. Penggunaan leverage memiliki tujuan untuk memberikan return kepada pemegang saham. Namun jika rasio leverage diperbesar maka menyebabkan ketidakpastian return juga akan semakin tinggi, tetapi juga tidak menutup kemungkinan return yang diperoleh nantinya juga akan tinggi sehingga nilai perusahaan bisa meningkat. Rasio leverage yang kecil menunjukkan bahwa rasio hutang perusahaan juga kecil. (Pratama \& Wiksuana, 2016) dan (Tarihoran, 2016) dalam penelitiannya menunjukkan bahwa leverage berpengaruh terhadap nilai perusahaan.

$\mathrm{H}_{4}$ : Leverage Berpengaruh Terhadap Nilai Perusahaan

\section{Metode Penelitian}

\subsection{Jenis Populasi dan Gambaran dari Populasi Penelitian (Objek) Penelitian}


Penelitian ini dengan menggunakan pendekatan kuantitatif. Teknik analisis data yang digunakan adalah analisis regresi linier berganda dengan menggunakan populasi seluruh perusahaan LQ 45 yang terdaftar di Bursa Efek Indonesia (BEI) tahun 2016-2019.

\subsection{Teknik Pengambilan Sampel}

Populasi yang digunakan dalam penelitian ini adalah seluruh perusahaan LQ 45 yang terdaftar di Bursa Efek Indonesia tahun 2016-2019 dengan menggunakan teknik purposive sampling dalam pengambilan sampelnya agar memperoleh hasil yang representative. Kriteria pengambilan sampel ialah; (1) Perusahaan yang telah listing di Bursa Efek Indonesia dan telah tercatat secara konsisten di dalam indeks LQ 45 pada periode 2016-2019; (2) Perusahaan yang menerbitkan laporan keuangan setiap tahunnya secara konsisten pada periode 2016-2019 dengan menggunakan mata uang rupiah

\subsection{Teknik Pengumpulan Data}

Teknik pengumpulan data yang digunakan adalah teknik dokumentasi yang diperoleh dari data yang telah dipublikasikan oleh masing-masing perusahaan. Kemudian juga melakukan penelitian keuangan di Bursa Efek Indonesia tahun 2016-2019 yang diperoleh melalui situs resmi Bursa Efek Indonesia.

\subsection{Definisi Operasional dan Pengukuran Variabel}

\subsubsection{Variabel Dependen}

Nilai perusahaan merupakan nilai jual suatu perusahaan sebagai sebuah bisnis yang sedang beroperasi (Sartono, 2010:487). Nilai perusahaan dalam penelitian ini diukur dengan menggunakan Price to Book Value (PBV). Dimana dalam rasio tersebut membandingkan antara harga per lembar saham dibagi dengan nilai buku per lembar saham. Rumus yang digunakan dalam mengukur variabel dependen adalah sebagai berikut :

$$
P B V=\frac{\text { Harga perlembar saham }}{\text { Nilai buku perlembar saham }}
$$

Dalam penelitian ini terdapat empat variabel bebas yakni :

\section{Profitabilitas}

Profitabilitas adalah kapasitas sebuah perusahaan guna memperoleh keuntungan baik itu berhubungan dengan penjualan, modal sendiri maupun total aset (Sartono, 2010:122). Profitabilitas dalam penelitian ini dihitung dengan menggunakan rumus sebagai berikut:

$$
R O E=\frac{\text { Laba bersih setelah pajak }}{\text { Ekuitas }}
$$

\section{Kepemilikan Institusional}

Kepemilikan institusional adalah kepemilikan saham yang dimiliki oleh pihak luar atau lembaga keuangan non bank maupun institusi (Widianingsih, 2018). Kepemilikan institusional dalam penelitian ini dihitung dengan menggunakan rumus sebagai berikut :

$$
\text { Kepemilikan Institusional }=\frac{\text { Kepemilikan saham institusional }}{\text { Jumlah saham yang beredar }}
$$




\section{Kebijakan Dividen}

Kebijakan dividen adalah salah satu kebijakan yang wajib diambil oleh pihak manajemen untuk memutuskan apakah laba yang diperoleh dalam suatu periode akuntansi dibagi semua atau sebagian sebagai dividen atau tidak dibagikan yang dimana disebut laba ditahan (Sutrisno, 2012:266). Kebijakan dividen dalam penelitian ini dihitung dengan menggunakan rumus sebagai berikut :

$$
D P R=\frac{\text { Dividen perlembar saham }}{\text { Laba per lembar saham }}
$$

\section{Leverage}

Leverage adalah kemampuan perusahaan dalam memakai harta yang mempunyai beban tetap guna memperbesar tingkat pendapatan untuk pemilik usaha (Syamsudin, 2007:147). Leverage dalam penelitian ini dihitung dengan rumus :

$$
D A R=\frac{\text { Total hutang }}{\text { Total aset }}
$$

\subsection{Teknik Analisis Data}

Metode analisis data adalah metode yang penting . hal ini dikarenakan dengan analisis, data diberi arti dan maksud yang berfungsi untuk memecahkan masalah penelitian. Teknik analisis data yang digunakan dalam penelitian ini adalah :

\subsubsection{Analisis Statistik Deskriptif}

Analisis statistik deskriptif merupakan gambaran maupun deskripsi suatu data yang dilihat melalui nilai rata-rata (mean), standar deviasi, varian, minimum, maksimum, range, sum, kurtosis dan skewness (kemencengan distribusi) (Ghozali, 2011:19)

\subsubsection{Uji Asumsi Klasik}

Uji asumsi klasik merupakan uji asumsi yang digunakan meliputi uji normalitas data, uji multikolinieritas, uji autokorelasi dan uji heteroskedastisitas.

\subsubsection{Uji Normalitas}

(Ghozali, 2018:161)uji normalitas data memiliki tujuan untuk menguji apakah dalam model regresi, residual atau variabel pengganggu mempunyai distribusi normal. Alat uji yang dapat digunakan dalam melihat kenormalan distribusi yaitu dengan melihat Normal Probability Plot.

\subsubsection{Uji Multikolinieritas}

Uji Multikolinieritas memiliki tujuan untuk mengetahui apakah di dalam data yang diuji terdapat hubungan atau korelasi yang tinggi antar variabel independen (Ghozali, 2018:107). Jika nilai VIF < 10 maka dapat dikatakan dalam model regresi tidak terdapat gejala multikolinieritas dan begitupun sebaliknya (Ghozali, 2018:107)

\subsubsection{Uji Heteroskedastisitas}


Pengujian dilakukan oleh peneliti guna mengetahui dan menguji apakah data didalam suatu model regresi, bisa terjadi ketidaksamaan varian dari residual satu pengamatan ke pengamatan yang lainnya. Hasil heteroskedastisitas pada suatu model regresi bisa dilihat pada pola gambar scatterplot. Ketika memperoleh hasil titik-titik data yang ada menyebar dan tidak terbentuk pola, maka dapat dikatakan tidak terjadi heteroskedastisitas pada data model regresi tersebut (Ghozali, 2018:137).

\subsubsection{Uji Autokolerasi}

Pengujian ini dilakukan untuk melihat korelasi antara periode $\mathrm{t}$ dengan periode $\mathrm{t}-1$ atau periode pada tahun sebelumnya (Ghozali, 2018:111-112). Model regresi bisa dikatakan bagus ketika model regresi dapat terbebas dari uji autokorelasi. Untuk dapat membuktikan ada tidaknya autokorelasi diantara periode tersebut di dalam suatu model regresi, maka bisa dilakukan dengan pengujian Durbin-Watson (uji DW) dengan membandingkan antara hasil DW hitung dengan hasil dalam tabel DW. Dasar dari pengambilan keputusan ada atau tidaknya gejala autokorelasi dalam model regresi yakni :

a. Bila $\mathrm{d}<\mathrm{dL}$ : terdapat autokorelasi negatif.

b. Bila $\mathrm{dL} \leq \mathrm{d} \leq \mathrm{dU}$ : tanpa keputusan.

c. Bila $\mathrm{dU} \leq \mathrm{d} \leq(4-\mathrm{dU})$ : tidak terdapat autokorelasi.

d. Bila $(4-\mathrm{dU}) \leq \mathrm{d} \leq(4-\mathrm{dL})$ : tanpa keputusan.

e. Bila $\mathrm{d} \geq(4-\mathrm{dL})$ : terdapat autokorelasi positif.

\subsubsection{Uji Regresi Linier Berganda}

Analisis regresi linier berganda digunakan untuk menguji pengaruh variabel independen (X) terhadap variabel dependen (Y). Berikut adalah persamaan regresinya :

Keterangan :

$$
\mathrm{PBV}=\alpha+\beta 1 \mathrm{ROE}+\beta 2 \mathrm{INST}+\beta 3 \mathrm{DPR}+\beta 4 \mathrm{DAR}+\varepsilon
$$

PBV :Price to Book Value (Nilai Perusahaan)

$\alpha \quad$ :Nilai Konstanta

$\beta \quad$ :Koefisien Regresi

ROE :Return on Equity (Profitabilitas)

INST :Institutional (Kepemilikan Institusional)

DPR :Dividen Payout Ratio (Kebijakan Dividen)

DAR :Debt to Asset Ratio (Leverage)

$\varepsilon \quad:$ Error

\section{Hasil Dan Pembahasan}

\subsection{Analisis Statistik Deskriptif}

Berdasarkan analisis data yang dilakukan oleh peneliti atas setiap variabel, maka hasilnya dapat dilihat pada tabel 1. Berdasarkan hasil perhitungan menggunakan SPSS yang ditunjukkan pada tabel 1 di atas sampel penelitian menjadi 90 data. Maka bisa disimpulkan:

1. Variabel profitabilitas yang dihitung dengan ROE (Return on Equity) memiliki nilai minimum 0,00 dan nilai maksimum sebesar 0,31. Nilai rata-rata adalah 0,1399 dengan standar deviasi 0,06112 .

2. Nilai maksimum untuk variabel kepemilikan institusional yang dihitung dengan INST (Institusional) sebesar 0.81 dan nilai minimum sebesar 0,00. Variabel kepemilikan institusional memiliki nilai standar deviasi sebesar 0,30869 dan nilai rata-rata sebesar 0,3021 .

3. Variabel kebijakan dividen yang dihitung dengan DPR (Dividend Payout Ratio) memiliki nilai standar deviasi sebesar 0,26497, nilai rata-rata sebesar 0,3768. Nilai minimum kebijakan dividen sebesar 0,00 dan nilai maksimum sebesar 1,03. 
4. Variabel leverage yang dihitung dengan DAR (Debt to Asset Ratio) memiliki nilai minimum sebesar 0,13 dan nilai maksimum sebesar 0,91. Variabel X4 ini memiliki nilai rata-rata sebesar 0,5199 dan nilai standar deviasi sebesar 0,22284.

5. Variabel nilai perusahaan yang dihitung dengan PBV (Price to Book Value) memiliki nilai standar deviasi sebesar 1,38431 dan nilai rata-rata sebesar 1,9611. Variabel tersebut memiliki nilai maksimum sebesar 6,77 dan nilai minimumnya sebesar 0,25.

Tabel 1

\begin{tabular}{|c|c|c|c|c|c|}
\hline & $\mathrm{N}$ & Minimum & Maximum & Mean & Std. Deviation \\
\hline MAN & 90 & ,00 & ,31 & ,1399 & ,06112 \\
\hline INST & 90 & ,00 & ,81 & ,3021 & ,30869 \\
\hline DPR & 90 & ,00 & 1,03 & ,3768 & ,26497 \\
\hline DAR & 90 & ,13 & 91 & ,5199 & ,22284 \\
\hline PBV & 90 & 25 & 6,77 & 1,9611 & 1,38431 \\
\hline Valid N (listwise) & 90 & & & & \\
\hline
\end{tabular}

\subsection{Uji Asumsi Klasik}

\subsection{Hasil Analisis Regresi Linier Berganda}

Uji regresi linier berganda memiliki tujuan untuk menguji hubungan antara variabel independent dengan variabel dependen. Berikut adalah hasil dari uji regresi linier berganda :

Tabel 2

\section{Hasil Analisis Regresi Linier Berganda}

\begin{tabular}{|c|c|c|c|c|c|c|c|c|}
\hline \multirow{2}{*}{\multicolumn{2}{|c|}{ Model }} & \multicolumn{2}{|c|}{$\begin{array}{l}\text { Unstandardized } \\
\text { Coefficients }\end{array}$} & \multirow{2}{*}{$\begin{array}{c}\begin{array}{c}\text { Standardized } \\
\text { Coefficients }\end{array} \\
\text { Beta }\end{array}$} & \multirow[b]{2}{*}{$\mathrm{t}$} & \multirow[b]{2}{*}{ Sig. } & \multicolumn{2}{|c|}{$\begin{array}{l}\text { Collinearity } \\
\text { Statistics }\end{array}$} \\
\hline & & B & Std. Error & & & & Tolerance & VIF \\
\hline \multirow[t]{5}{*}{1} & Constant) & 1,314 & ,549 & & 2,393 & ,019 & & \\
\hline & ROE & 9,769 & 1,988 & ,431 & 4,914 &, 000 & ,741 & 1,349 \\
\hline & INST &, 153 & ,504 & ,034 & ,304 & ,762 & ,453 & 2,210 \\
\hline & DPR & ,776 & ,446 & , 149 & 1,741 & ,085 & ,784 & 1,275 \\
\hline & DAR & $-2,035$ & ,684 &,- 328 & -2974 & ,004 & , 470 & 2,125 \\
\hline
\end{tabular}

$\mathrm{PBV}=1,314+9,769 \mathrm{X} 1+0,153 \mathrm{X} 2+0,776 \mathrm{X} 3-2,035 \mathrm{X} 4+\varepsilon$

Melihat persamaan regresi linier berganda di atas, dapat diinterpretasikan sebagai berikut :

1. Nilai konstanta $(\alpha)$ dalam penelitian ini sebesar 1,314, dimana nilai tersebut menunjukkan apabila koefisien regresi variabel independen pada persamaan regresi sama dengan nol atau konstan, maka tingkat nilai perusahaan bernilai sebesar 1,314.

2. Nilai koefisien regresi pada variabel profitabilitas yang dihitung dengan ROE (Return on Equity) (sebesar 9,769. Adanya hal tersebut menunjukkan apabila kenaikan profitabilitas sebesar satu satuan, maka mengakibatkan meningkatnya nilai perusahaan sebesar 9,769.

3. Nilai koefisien regresi pada variabel kepemilikan institusional yang dihitung dengan INST (Institusional) memiliki nilai sebesar 0,153. Hal ini menunjukkan apabila terjadi kenaikan kepemilikan institusional sebesar satu satuan, maka mengakibatkan kenaikan nilai perusahaan sebesar 0,153 . 
4. Nilai koefisien regresi pada variabel kebijakan dividen yang dihitung dengan DPR (Dividend Payout Ratio) memiliki nilai sebesar 0,776. Adanya hal tersebut menunjukkan bahwa jika terjadi kenaikan kebijakan dividen sebesar satu satuan, maka dapat mengakibatkan naiknya nilai perusahaan sebesar 0.776 .

5. Nilai koefisien regresi pada variabel leverage yang dihitung dengan DAR (Debt to Asset Ratio) memiliki nilai sebesar -2,035. Hal tersebut menunjukkan bahwa, jika terjadi penurunan leverage sebesar satu satuan dapat mengakibatkan penurunan terhadap nilai perusahaan sebesar 2,035.

\subsection{Uji Hipotesis}

\subsubsection{Uji Parsial (Uji t)}

Uji parsial memiliki tujuan untuk mengetahui pengaruh variabel independen secara parsial terhadap variabel dependen. Apabila nilai signifikansinya $<5 \%$, maka terdapat pengaruh signifikansi antara satu variabel independent terhadap variabel dependen ataupun sebaliknya. Apabila t hitung $>\mathrm{t}$ tabel dengan $\alpha=5 \%$ maka menunjukkan adanya pengaruh signifikansi antara variabel independen terhadap variabel dependen. Penentuan Hipotesis Uji t adalah sebagai berikut :

a. Ho $=$ Variabel independen secara parsial tidak berpengaruh terhadap variabel dependen.

b. $\mathrm{H}_{1}=$ Variabel independen secara parsial berpengaruh terhadap variabel dependen. Berikut adalah hasil Uji Parsial (Uji t) :

Berdasarkan tabel 2 di atas menunjukkan berapa besarnya nilai thitung. Untuk mengambil kesimpulan dari hasil uji t, maka kita harus menghitung t tabel terlebih dahulu. Nilai tabel dapat diketahui dari N-K, dimana $\mathrm{N}$ merupakan jumlah sampel dan $\mathrm{K}$ merupakan jumlah variabel dependen dan variabel independen. Sehingga $\mathrm{df}=90-5=85$, maka t tabel adalah sebesar 1,988 dengan signifikansi sebesar 5\%.

\subsubsection{Uji Simultan (Uji F)}

Uji simultan merupakan uji yang digunakan untuk mengetahui apakah semua variabel independen dalam model memiliki pengaruh terhadap variabel dependen secara bersamaan. Apabila tingkat signifikansinya $<0,05$ maka diartikan terdapat pengaruh yang signifikan simultan antara variabel independen terhadap variabel dependen. Jika $\mathrm{F}_{\text {hitung }}>\mathrm{F}_{\text {tabel }}$ dengan $\alpha=$ 5\% maka dapat dikatakan bahwa variabel independen secara simultan berpengaruh terhadap variabel dependen. Berikut ini merupakan hasil dari uji simultan (Uji F) :

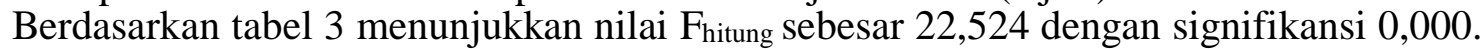
Uji simultan membandingkan antara besarnya Fhitung dengan $\mathrm{F}_{\text {tabel }}$ yang diperoleh dari $\mathrm{df}_{1}=$ $\mathrm{K}-1$, dimana $\mathrm{K}$ adalah jumlah variabel penelitian. Untuk mencari $\mathrm{df}_{2}=\mathrm{N}-\mathrm{K}$, dimana $\mathrm{N}$ merupakan jumlah sampel penelitian. Berdasarkan hasil perhitungan diperoleh hasil $\mathrm{df}_{1=} 4$ (51) dan nilai dari $\mathrm{df}_{2}=85$ (90-5). $\mathrm{Ft}_{\text {abel }}$ diperoleh hasil sebesar 2,48. Dengan demikian dapat disimpulkan bahwa variabel independen profitabilitas, kepemilikan institusional, kebijakan dividen dan leverage secara simultan berpengaruh terhadap variabel dependen nilai perusahaan, dengan hasil $\mathrm{F}_{\text {hitung }}>\mathrm{F}_{\text {tabel }}$ yaitu 22,524 $>2,48$ dengan tingkat signifikansi dibawah $0,05(5 \%)$ yaitu sebesar 0,000 .

Tabel 3

\section{Hasil Uji Simultan (Uji F)}

\begin{tabular}{llrr|r|r|r}
\hline Model & & Sum of Squares & Df & Mean Square & F & \multicolumn{1}{c}{ Sig. } \\
\hline 1 & Regression & 87,758 & 4 & 21,939 & 22,524 &, $000^{\mathrm{b}}$ \\
\cline { 2 - 7 } & Residual & 82,795 & 85 &, 974 & & \\
\cline { 2 - 7 } & Total & 170,552 & 89 & & & \\
\hline
\end{tabular}

a. Dependent Variable: PBV

b. Predictors:(Constant),DER,DPR,INST,ROE 


\subsubsection{Uji Koefisien Determinasi}

Uji koefisien determinasi $\left(\mathrm{R}^{2}\right)$ merupakan uji yang digunakan untuk mengukur seberapa besar kemampuan variabel independen terhadap variabel dependen. Hasil uji koefisien determinasi bisa dilihat dari tabel dibawah ini :

\section{Tabel 4 \\ Hasil Uji Koefisien Determinasi}

\begin{tabular}{|c|c|c|c|c|c|}
\hline Model & $\mathrm{R}$ & R Square & $\begin{array}{c}\text { Adjusted R } \\
\text { Square } \\
\end{array}$ & $\begin{array}{c}\text { Std. Error of the } \\
\text { Estimate }\end{array}$ & Durbin-Watson \\
\hline 1 & $.717^{\mathrm{a}}$ & .515 & .492 & .98694 & 2.012 \\
\hline
\end{tabular}

Berdasarkan tabel 4.15 dapat diketahui nilai Adjust $R$ Square sebesar 0,492. Oleh karena itu disimpulkan bahwa nilai perusahaan dapat dijelaskan oleh profitabilitas, kepemilikan institusional, kebijakan dividen dan leverage sebesar 49,2\% sedangkan sisanya sebesar 50,8\% dijelaskan oleh variabel lain yang tidak terdapat dalam variabel penelitian ini.

\section{Pembahasan}

\subsubsection{Pengaruh Profitabilitas Terhadap Nilai Perusahaan}

Output perhitungan uji parsial menunjukkan hasil t hitung sebesar 4,914 dengan signifikansi sebesar 0,000. Berdasarkan hasil pengujian pengaruh profitabilitas terhadap nilai perusahaan menunjukkan bahwa profitabilitas berpengaruh terhadap nilai perusahaan. Hasil dari penelitian ini mendukung teori sinyal yang mana jika profitabilitas dalam suatu perusahaan meningkat, dapat memberikan sinyal yang baik kepada investor untuk menanamkan modalnya pada perusahaan. Profitabilitas yang meningkat menyebabkan nilai perusahaan juga meningkat pula. Perusahaan yang memiliki profitabilitas yang tinggi diyakini memiliki kecukupan dana, sehingga dapat mendukung perusahaan untuk meningkatkan kinerjanya menjadi lebih baik. Dengan kualitas kinerja perusahaan yang baik bisa memberikan dampak yang positif di masa yang akan datang, sehingga nilai perusahaan bisa meningkat.

Hasil penelitian ini sejalan dengan penelitian yang telah dilakukan oleh peneliti terdahulu, seperti penelitian yang dilakukan oleh (Mardevi et al., 2020) dan juga (Oktrima, 2017) dimana dalam penelitiannya diperoleh hasil nilai perusahaan dipengaruhi oleh profitabilitas.

\subsubsection{Pengaruh Kepemilikan Institusional Terhadap Nilai Perusahaan}

Berdasarkan hasil uji parsial (uji t) diperoleh output t hitung sebesar 0,304 dengan signifikansi sebesar 0,762. Berdasarkan hasil tersebut menunjukkan kepemilikan institusional tidak berpengaruh terhadap nilai perusahaan. Hal ini dikarenakan besarnya t hitung kurang dari daripada $t$ tabel, di mana $t$ tabel dalam penelitian ini sebesar 1,988. Hasil penelitian ini tidak mendukung teori agensi yang dimana kepemilikan institusional tinggi maka bisa meningkatkan pengawasan yang lebih optimal, sehingga nantinya manajer dapat meningkatkan tanggungjawabnya dalam mengembangkan perusahaan yang diharapkan dapat meningkatkan nilai perusahaan.

Hasil penelitian ini sejalan dengan penelitian yang dilakuka oleh (Kartika Dewi \& Abundanti, 2019) dan (Warapsari \& Suaryana, 2016) dimana kepemilikan institusional yang diproksikan dengan INST tidak berpengaruh terhadap nilai perusahaan. Penurunan kepemilikan institusional belum mampu untuk mencerminkan nilai perusahaan. 


\subsubsection{Pengaruh Kebijakan Dividen Terhadap Nilai Perusahaan}

Berdasarkan hasil pengujian uji parsial (uji t) diperoleh output t hitung sebesar 1,741 dengan nilai signifikansi sebesar 0,085 . Dengan adanya hasil tersebut, dapat disimpulkan bahwa kebijakan dividen tidak berpengaruh terhadap nilai perusahaan. Hal ini dikarenakan besarnya $\mathrm{t}$ hitung kurang dari $\mathrm{t}$ tabel, dimana $\mathrm{t}$ tabel dalam penelitian ini sebesar 1,988. Hasil penelitian ini tidak mendukung adanya teori sinyal dimana jika kebijakan dividen tinggi maka nilai perusahaan juga tinggi. Adanya dividen yang tinggi tidak menjadikan investor tertarik untuk menanamkan modalnya. Hal ini menunjukkan bahwa dividen yang menurun maka dapat mengakibatkan nilai perusahaan semakin meningkat. Hal ini dikarenakan jika dividen menurun maka laba ditahan perusahaan akan semakin meningkat sehingga kinerja perusahaan juga akan meningkat sehingga nilai perusahaan juga akan meningkat.

Penelitian ini sejalan dengan penelitian yang dilakukan oleh (Wijoyo, 2018) dan (Martha et al., 2018) dimana kebijakan dividen yang diproksikan dengan Dividend Payout Ratio (DPR) tidak berpengaruh terhadap nilai perusahaan. Hal ini menunjukkan bahwa kebijakan dividen yang ditentukan oleh perusahaan belum cukup untuk menjelaskan pengaruhnya terhadap nilai perusahaan.

\subsubsection{Pengaruh Leverage Terhadap Nilai Perusahaan}

Berdasarkan hasil pengujian uji parsial (uji t) diperoleh hasil nilai t thitung sebesar -2,974 dan signifikansi sebesar 0,004 . Adanya output tersebut menunjukkan bahwa leverage berpengaruh dengan arah berlawanan (negatif) terhadap nilai perusahaan. Hal ini dikarenakan t hitung lebih besar dibandingkan dengan t tabel. Hal ini tidak sejalan dengan teori sinyal dimana ketika leverage meningkat maka dapat mengakibatkan nilai perusahaan juga ikut meningkat. Ketika nilai leverage meningkat menunjukkan bahwa jumlah hutang yang dimiliki oleh perusahaan juga meningkat pula. Dengan nilai leverage yang meningkat dapat mengakibatkan bahwa resiko dalam berinvestasi juga semakin tinggi, yang dimana nantinya bisa menurunkan minat investor dalam menanamkan modalnya pada perusahaan tersebut. Dengan adanya kondisi yang sedemikian rupa bisa mengakibatkan nilai perusahaan menjadi menurun.

Hasil dari penelitian ini sejalan dengan penelitian yang dilakukan oleh (Pratama \& Wiksuana, 2016) dan (Tarihoran, 2016) dimana dalam penelitiannya menyebutkan bahwa leverage berpengaruh terhadap niali perusahaan. Perusahaan yang mampu melunasi hutanghutang jangka panjangnya maka dapat mengakibatkan kinerja perusahaan semakin meningkat sehingga nilai perusahaan juga mengalami kenaikan.

\section{Kesimpulan Dan Saran}

\subsection{Simpulan}

Berdasarkan hasil dan pembahasan data yang telah diuji di atas, dapat disimpulkan bahwa Variabel profitabilitas parsial berpengaruh terhadap nilai perusahaan. Variabel kepemilikan institusional dan kebijakan dividen secara parsial tidak berpengaruh terhadap nilai perusahaan. Variabel leverage secara parsial berpengaruh terhadap nilai perusahaan dengan arah yang berlawanan (negatif). Variabel profitabilitas, kepemilikan institusional, kebijakan dividen dan leverage secara simultan berpengaruh terhadap nilai perusahaan. Intensitas pengaruh yang diwakili oleh uji koefisien determinasi $\left(\mathrm{R}_{2}\right)$ menunjukkan kemampuan variabel independen dalam menjelaskan variabel dependen yaitu sebesar 49,2\% sedangkan sisanya 50,8\% dijelaskan oleh variabel lainnya yang tidak termasuk dalam penelitian ini.

\subsection{Keterbatasan}

Waktu dalam pengamatan masih dianggap terlalu singkat, karena hanya meneliti dari tahun 2016-2019. Dalam proses penulisan, peneliti dianggap masih kurang teliti karena terdapat kata yang mengalami kesalahan penulisan. 


\subsection{Saran}

Beberapa yang bisa diberikan atas hasil yang telah diperoleh oleh peneliti adalah Dari hasil penelitian yang telah dilakukan, seharusnya perusahaan harus selalu berupaya untuk meningkatkan kinerja perusahaan sehingga dapat memberikan dampak yang positif untuk jangka panjang di waktu mendatang. Saran yang dapat diberikan kepada investor atas hasil penelitian ini adalah, hendakanya investor lebih teliti lagi dalam menganalisa bagaimana kinerja perusahaan tersebut, baik melalui harga saham, kinerja perusahaan, profitabilitas dan lain sebagainya. Dengan melihat hasil $\mathrm{R}$ square maka disarankan peneliti selanjutnya bisa menambah variabel penelitian yang lainnya seperti kebijakan hutang, modal kerja, keputusan investasi dan lain-lain yang dapat mempengaruhi nilai perusahaan.

\section{Referensi}

Apriada, K., \& Suardhika, M. S. (2016). Pengaruh Struktur Kepemilikan Saham, Struktur Modal Dan Profitabilitas Pada Nilai Perusahaan. E-Jurnal Ekonomi Dan Bisnis Universitas Udayana, 5, 201-218.

Arifianto, M., \& Chabachid, M. (2016). Analisis Faktor-Faktor Yang Mempengaruhi Nilai Perusahaan ( Studi Kasus Pada Perusahaan Yang Terdaftar Pada Indeks Lq-45 Periode 2011-2014). Diponegoro Journal Of Management, 5(1), 1-12.

Ayu, D. P., \& Suarjaya, A. A. G. (2017). Pengaruh Profitabilitas Terhadap Nilai Perusahaan Dengan Corporate Social Responsibility Sebagai Variabel Mediasi Pada Perusahaan Pertambangan. E-Jurnal Manajemen Unud, 6, 1112-1138.

Dewi, L. S., \& Abundanti, N. (2019). Pengaruh Profitabilitas, Likuiditas, Kepemilikan Institusional Dan Kepemilikan Manajerial Terhadap Nilai Perusahaan. E-Jurnal $\begin{array}{llll}\text { Manajemen Universitas } & \text { Udayana, } & \text { 8(10), }\end{array}$ Https://Doi.Org/10.24843/Ejmunud.2019.V08.I10.P12

Dewi Lusiana, \& Agustina, D. (2017). Aulia Fuad Rahman. Jurnal Bisnis Dan Akuntansi, 18, 81-91.

Dwi, K., \& Pradnyana, D. (2018). Moderasi Corporate Social Responsibility Pada Pengaruh Profitabilitas Terhadap Nilai Perusahaan Pada Perusahaan Manufaktur. E-Jurnal Akuntansi, 24(1), 253-281. Https://Doi.Org/10.24843/Eja.2018.V24.I01.P10

Ghozali, I. (2011). Aplikasi Analisis Multivariate Dengan Program Spss. Bp Universitas Diponegoro.

Ghozali, I. (2018). Aplikasi Analis Multivariate Dengan Program Ibm Spss 25. Badan Penerbit Universitas Diponegoro.

Gumanti, T. A. (2009). Teori Sinyal Dalam Manajemen Keuangan. Manajemen Usahawan Indonesia.

Hamdiah, C. (2015). Pengaruh Kepemilikan Institusional Dan Kualitas Laba Terhadap Nilai Perusahaan Pada Perusahaan Transportasi Yang Terdaftar Di Bursa Efek Indonesia. Jurnal Ekonomi Manajemen Dan Akuntansi. Universitas Serambi Mekkah Banda Aceh, Vol.1(No.1. Tahun 2015), Pp: 1-9. Issn: 2460-5891.

Haruman, T. (2008). Pengaruh Struktur Kepemilikan Terhadap Keputusan Keuangan Dan Nilai Perusahaan Survey Pada Perusahaan Manufaktur Di Pt. Bursa Efek Indonesia. Universitas Widyatama, $150-166$.

Http://Repository.Widyatama.Ac.Id/Xmlui/Handle/123456789/3311

Idawati, W. (2016). Analisis Faktor-Faktor Yang Mempengaruhi Nilai Perusahaan Pada Perusahaan Makanan Dan Minuman Yang Terdaftar Di Bursa Efek Indonesia Periode 2012-2016. 10, 152-166.

Jayaningrat, I. G. A. A., Wahyuni, M. A., \& Sujana, E. (2017). Pengaruh Leverage, Profitabilitas, Likuiditas, Kebijakan Deviden, Kepemilikan Manajerial, Dan Kepemilikan 
Institusional Terhadap Nilai Perusahaan Pada Perusahaan Properti Dan Real Estate Di Bursa Efek Indonesia Tahun 2013-2015. E-Journal S1 Akuntansi Universitas Pendidikan Ganesha, $7(1)$ $1-12$. Https://Ejournal.Undiksha.Ac.Id/Index.Php/S1ak/Article/View/10148

Jensen, M. C., \& Meckling, W. H. (1976). Theory Of The Firm : Managerial Behavior, Agency Cost And Ownership Struktur. Journal Of Financial Economics, 3.

Kartika Dewi, N. P. I., \& Abundanti, N. (2019). Pengaruh Leverage Dan Ukuran Perusahaan Terhadap Nilai Perusahaan Dengan Profitabilitas Sebagai Variabel Mediasi. E-Jurnal $\begin{array}{llll}\text { Manajemen Universitas } \quad \text { Udayana, } & 8(5),\end{array}$ Https://Doi.Org/10.24843/Ejmunud.2019.V08.I05.P16

Kasmir. (2012). Analisis Laporan Keuangan. Pt. Raja Grafindo Persada.

Lestari, L. (2017). Pengaruh Kepemilikan Institusional Dan Struktur Modal Terhadap Nilai Perusahaan. Jurnal Riset Manajemen Dan Bisnis (Jrmb) Fakultas Ekonomi Uniat, 2(September), 293-306. Https://Doi.Org/10.36226/Jrmb.V2is1.62

Lubis, I. L., Sinaga, B. M., \& Sasongko, H. (2017). Pengaruh Profitabilitas, Sruktur Modal, Dan Likuiditas Terhadap Nilai Perusahaan. Jurnal Aplikasi Bisnis Dan Manajemen, 3(3), 458-465. Https://Doi.Org/10.17358/Jabm.3.3.458

Mardevi, K. S., Suhendro, \& Riana, R. D. (2020). Faktor- Faktor Yang Mempengaruhi Nilai Perusahaan Dengan Struktur Modal Sebagai Variabel Moderasi. Jurnal Akuntansi \& Ekonomi Fe. Un Pgri Kediri, 5(2), 36-47.

Martha, L., Sogiroh, N. U., Magdalena, M., Susanti, F., \& Syafitri, Y. (2018). Profitabilitas Dan Kebijakan Dividen Terhadap Nilai Perusahaan. Jurnal Benefita, 3(2), 227. Https://Doi.Org/10.22216/Jbe.V3i2.3493

Oktrima, B. (2017). Pengaruh Profitabilitas, Likuiditas, Dan Struktur Modal Terhadap Nilai Perusahaan (Studi Empiris: Pt. Mayora Indah, Tbk. Tahun 2011 - 2015). 1(1), 98-107.

Pasaribu, M. Y., Topowijono, \& Sri Sulasmiyati. (2016). Pengaruh Struktur Modal, Struktur Kepemilikan Dan Profitabilitas Terhadap Nilai Perusahaan Pada Perusahaan Sektor Industri Dasar Dan Kimia Yang Terdaftar Di Bei Tahun 2011-2014. Jurnal Administrasi Bisnis (Jab)|, 35, 154-164.

Petronila, A. ., \& Mukhlasin. (2003). Pengaruh Profitabilitas Perusahaan Terhadap Ketepatan Waktu Pelaporan Laporan Keuangan Dengan Opini Audit Sebagai Moderating Variabel. Jurnal Ekonomi Dan Bisnis.

Pratama, I. G. B. A., \& Wiksuana, I. G. B. (2016). Pengaruh Ukuran Perusahaan Dan Leverage Terhadap Nilai Perusahaan Dengan Profitabilitas Sebagai Variabel Mediasi. E-Jurnal Manajemen Unud, 5, 1338-1367.

Putra, A. N. D. A., \& Lestari, P. V. (2016). Pengaruh Kebijakan Dividen, Likuiditas, Profitabilitas Dan Ukuran Perusahaan Terhadap Nilai Perusahaan. E-Jurnal Manajemen Unud, 5, 4044-4070.

Raharjo, E. (2007). Teori Agensi Dan Teori Stewarship Dalam Perspektif Akuntansi. Fokus Ekonomi, 2, 37-46.

Rahayu, M., \& Sari, B. (2018). Faktor-Faktor Yang Mempengaruhi Nilai Perusahaan. IkraithHumaniora, 2, 69-76.

Rai Prastuti, N., \& Merta Sudiartha, I. (2016). Pengaruh Struktur Modal, Kebijakan Dividen, Dan Ukuran Perusahaan Terhadap Nilai Perusahaan Pada Perusahaan Manufaktur. None, 5(3), 254202.

Riyanto, B. (2010). Dasar-Dasar Pembelanjaan Perusahaan (4th Ed.). Bpfe.

Rizqia, D. A., Aisjah, S., Program, P., \& Java, E. (2013). Effect Of Managerial Ownership , Financial Leverage, Profitability, Firm Size, And Investment Opportunity On Dividend Policy And Firm Value. 4(11), 120-130. 
Sartono, A. (2010). Manajemen Keuangan Teori Dan Aplikasi (4th Ed.). Bpfe.

Senata, M. (2016). Pengaruh Kebijakan Dividen Terhadap Nilai Perusahaan Yang Tercatat Pada Indeks Lq-45 Bursa Efek Indonesia. Jurnal Wira Ekonomi Mikrosil, 6(01), 73-84.

Sholekah, F. W., \& Venusita, L. (2014). Pengaruh Kepemilikan Manajerial, Kepemilikan Institusional, Leverage, Firm Size, Dan Corporate Social Responsibility Terhadap Nilai Perusahaan Pada Perusahaan High Profile Yang Terdaftar Di Bursa Efek Indonesia Periode 2008-2012. Jurnal Ilmu Manajemen, 2(3), 795-807.

Sinarmayarani, A., \& Suwitho. (2016). Pengaruh Kepemilikan Institusional Dan Profitabilitas Terhadap Nilai Perusahaan Melalui Kebijakan Dividen Adhita. Jurnal Ilmu Dan Riset Manajemen, 5(5), 1-20.

Suharli, Ign, J., \& Michell. (2006). Akuntansi Untuk Bisnis Jasa Dan Dagang.

Sutrisno. (2009). Manajemen Keuangan Teori, Konsep Dan Aplikas (Pertama). Ekonisia.

Sutrisno. (2012). Manajemen Keuangan Teori, Konsep Dan Aplikasi. Ekonisia.

Suwardika, I., \& Mustanda, I. (2017). Pengaruh Leverage, Ukuran Perusahaan, Pertumbuhan Perusahaan, Dan Profitabilitas Terhadap Nilai Perusahaan Pada Perusahaan Properti. None, 6(3), 254488.

Syamsudin, L. (2007). Manajemen Keuangan Perusahaan. Pt Raja Grafindo Persada.

Tarihoran, A. (2016). Pengaruh Penghindaran Pajak Dan Leverage Terhadap Nilai Perusahaan Dengan Transparansi Perusahaan Sebagai Variabel Moderasi. Jurnal Wira Ekonomi Mikroskil, 6(2), 149-164.

Tewuh, N. E., Murni, S., Maramis, J. B., Perusahaan, P., Tidak, Y., Dividen, M., \& Industri, D. I. (2020). Sub Sektor Logam Dan Lainnya Yang Terdaftar Di Bei ) Factors Affecting The Value Of The Company ( In Companies That Do Not Share Dividends In The Metal And Other Sub Sector Manufacturing Industries Listed On The Idx ). 8(1), 212-221.

Ulistianingsih, E. D., \& Yuniati, T. (2016). Pengaruh Kepemilikan Manajerial Dan Profitabilitas Terhadap Nilai Perusahaan Melalui Kebijakan Dividen. Jurnal Ilmu Dan Riset Manajemen, 5(5), 1-20. Https://Scholar.Google.Co.Id/Scholar?Hl=Id\&As_Sdt=0\%2c5\&Q=Ulistianingsih\%2c+ E.+D.\%2c+\%26+Yuniati\%2c+T.+\%282016\%29.+Pengaruh+Kepemilikan+Manajerial+ Dan+Profitabilitas+Terhadap+Nilai+Perusahaan+Melalui+Kebijakan+Dividen\&Btng=

Warapsari, A. A. A. U., \& Suaryana, I. G. N. A. (2016). Pengaruh Kepemilikan Manajerial Dan Institusional Terhadap Nilai Perusahaan Dengan Kebijakan Utang Sebagai Variabel Intervening. E-Jurnal Akuntansi Universitas Udayana, 16(3), 2288-2315.

Wardhani, T. S., Chandrarin, G., \& Rahman, A. F. (2012). Pengaruh Kepemilikan Institusional Terhadap Nilai Perusahaan Dengan Keputusan Investasi ,. Jurnal Ilmiah Akuntansi, Keuangan Dan Pajak, 1(2), 93-110.

Widianingsih, D. (2018). Kepemilikan Manajerial, Kepemilikan Institusional, Komisaris Independen, Serta Komite Audit Pada Nilai Perusahaan Dengan Pengungkapan Csr Sebagai Variabel Moderating Dan Firm Size Sebagai Variabel Kontrol. Jurnal Akuntansi Dan Pajak, 19(1), 38. Https://Doi.Org/10.29040/Jap.V19i1.196

Wijoyo, A. (2018). Faktor-Faktor Yang Mempengaruhi Nilai Perusahaan Pada Perusahaan Property Dan Real Estate Di Bursa Efek Indonesia. Jurnal Ekonomi, 23(1), 48-61. Https://Doi.Org/10.24912/Je.V23i1.333 